\title{
Bioproduction of 4-vinylphenol from corn cob alkaline hydrolyzate in two-phase extractive fermentation using free or immobilized recombinant E. coli expressing pad gene
}

\author{
José Manuel Salgado ${ }^{c, *}$, Raquel Rodríguez-Solana ${ }^{\mathrm{a}, \mathrm{b}}$, José Antonio Curiel ${ }^{\mathrm{d}}$, \\ Blanca de las Rivas ${ }^{\mathrm{d}}$, Rosario Muñoz ${ }^{\mathrm{d}}$, José Manuel Domínguez ${ }^{\mathrm{a}, \mathrm{b}}$ \\ a Laboratory of Agro-food Biotechnology, CITI-Tecnólopole, Parque Tecnológico de Galicia, San Cibrao das Viñas, Ourense, Spain \\ ${ }^{\mathrm{b}}$ Department of Chemical Engineering, Sciences Faculty, University of Vigo (Campus Ourense), As Lagoas s/n, 32004 Ourense, Spain \\ ' IBB-Institute for Biotechnology and Bioengineering, Centre of Biological Engineering, University of Minho, Campus de Gualtar, 4710-057 Braga, Portugal \\ d Laboratorio y Tecnología de Alimentos y Nutrición, ICTAN-CSIC, Juan de la Cierva 3, 28006 Madrid, de Biotecnología Bacteriana, Instituto de Ciencia, Spain
}

\section{A R T I C L E I N F O}

\section{Article history:}

Received 28 November 2013

Received in revised form 6 February 2014

Accepted 9 February 2014

Available online 20 February 2014

\section{Keywords:}

Extractive fermentation

4-Vinylphenol

Corn cobs

Immobilized cells

\begin{abstract}
A B S T R A C T
In situ extractive fermentation was used to produce 4-vinyl derivatives from hydroxycinnamic acids extracted from corn cobs by recombinant Escherichia coli cells expressing Lactobacillus plantarum phenolic acid descarboxylase (PAD) gene. This microorganism mainly produced 4-vinylphenol (4VP) from $p$-coumaric acid ( $p$-CA). In the first study, we observed that the concentrations of $4 \mathrm{VP}$ are higher than $1 \mathrm{~g} / \mathrm{L}$ which had a negative impact on decarboxylation of $p$-CA to $4 \mathrm{VP}$ by recombinant $E$. coli cells. Because of this, and in order to improve the downstream process, a two-phase aqueous-organic solvent system was developed. The results of the extractive fermentation indicated that it was possible to use hydrolyzates as aqueous phase to bioproduce $4 \mathrm{VP}$, and recover simultaneously the product in the organic phase containing hexane. The detoxification of pre-treated corn cob alkaline hydrolyzate improved 4VP production up to $1003.5 \mathrm{mg} / \mathrm{L}$ after $24 \mathrm{~h}$ fermentation $\left(Q_{P}=41.813 \mathrm{mg} / \mathrm{L} \mathrm{h}\right)$. Additionally, preliminary experiments using cells immobilized in calcium alginate showed to be a good system for the biotransform of $p$-CA to $4 \mathrm{VP}$ in extractive fermentation, although the process hindered partially the recovery of $4 \mathrm{VP}$ in the organic phase.
\end{abstract}

(c) 2014 Elsevier Inc. All rights reserved.

\section{Introduction}

4-Vinylphenol (4VP), also known as 4-hydroxystyrene or hydroxystyrene monomer (CAS 2628-17-3), is a volatile compound which can be produced from $p$-coumaric acid ( $p$-CA). Due to its inherent reactivity, it can only be marketed in maximum alcoholic solution (propylene glycol) concentrations not exceeding $10 \%$ $(\mathrm{w} / \mathrm{w})$ of the vinyl monomer [1]. 4VP finds application as a polymer precursor or as a flavoring substance in perfumery, food and beverages industries being approved as FEMA GRAS (Flavor and Extract Manufacturer's Association; General Regarded as Safe) [2]. In addition, 4VP can be used as antifungal agent [3]. The chemical synthesis can be carried out by Knoevenagel condensation of benzaldehydes with malonic acid and classical acidic [4]. Chemical synthesis can need expensive reagents and harsh conditions

\footnotetext{
* Corresponding author. Tel.: (+34) 988 387416; fax: +34 988470330.

E-mail address: jmsalgado@uvigo.es (J.M. Salgado).
}

and low yields are obtained [2]. The biotechnological production is possible by enzymatic decarboxylation of $p$-CA $[5,6]$.

Lignocellulosic materials are a source of $p$-CA which is known to be esterified essentiality only to the lignin [7]. Significant amounts of $p$-CA can be released from corn cobs. These agro-industrial wastes are generated during shelling of corn, being estimated that for every $100 \mathrm{~kg}$ of corn grain approximately $18 \mathrm{~kg}$ corn cobs are produced [8]. p-CA is a potential precursor in the biocatalytic production of value-added aromatic natural products [9]. Lignocellulosic materials are treated to fractionate their principal components cellulose, hemicelluloses, lignin or extracts. Dilute acid pre-treatment is commonly used during fractionation of lignocellulosic materials for the selective extraction of hemicelluloses [10]. Alkaline hydrolysis is a process that easily dissolves lignin, allowing for the complete utilization of the lignocellulosics with a low environmental impact [11].

Two-phase biotransformation system (TPBS) or extractive fermentation is a technique that allows recovering the product along of fermentation. This system has been widely used in biotechnology 
for the extraction and purification bioproducts [12,13]. It is an ideal system for the retrieval of hydrophilic products as vinyl derivatives, since the coexistence of two phases (aqueous and organic) permits the ready separation of the lipophilic products vinyl derivatives from the more hydrophilic substrate hydroxycinnamic acids [14]. This system has been used for the biotechnological production of 4VP, 4 vinyl guaiacol, lauryl lactone or 2-phenylethanol [1,14-16]. In problems with inhibition by product, extractive fermentation can be a good solution for simultaneous cell cultivation and downstream processing of product.

Combined of TPBS and immobilization of microorganisms allow to reuse cells and also prevent direct contact of cell with organic phase, therefore avoiding phase toxicity [17]. There are several immobilization methods including calcium alginate. This immobilization system not need hard conditions, has a low cost method and it is common its use in foods [18].

This work researched the product inhibition of 4VP in recombinant Escherichia coli cells overproducing the phenolic acid decarboxylase (PAD) enzyme from Lactobacillus plantarum CECT $748^{\mathrm{T}}$ and the use of a TPBS process in alkaline hydrolyzate of corn cobs to avoid this problem.

\section{Materials and methods}

\subsection{Chemicals and raw material}

The phenolic acids, ferulic acid (FA) (128708) and p-CA (C9008) as well as the corresponding 4-vinylphenol derivatives, 4-vinyl guaiacol (4VG) (W267511) and 4VP (W373923), respectively, were purchased to Sigma-Aldrich (Madrid, Spain) as standards for compound identification by HPLC. Tryptone (403682), NaCl (131659), yeast extract (403687), and methanol HPLC grade (221091) were supplied by Panreac (Barcelona, Spain), meanwhile ampicillin (A9518) was supplied by Sigma-Aldrich, S. A. (Madrid, Spain).

Corn cobs employed in this work were donated by farmers in the area of Ourense (Galicia, Spain), dried at room temperature and milled to a particle size suitable for acid hydrolysis $(<5 \mathrm{~mm})$. Corn cobs were characterized by quantitative acid hydrolysis [19]. The composition expressed in percentage (oven-dry basis) was: cellulose: $31.5 \mathrm{~g} \mathrm{~L}^{-1} \pm 1.5$; hemicelluloses: $34.9 \mathrm{~g} \mathrm{~L}^{-1} \pm 0.3$; acetyl groups: $4.1 \mathrm{~g} \mathrm{~L}^{-1} \pm 0.6$ and lignin: $21.6 \mathrm{~g} \mathrm{~L}^{-1} \pm 1.5$ [18]. Zhang et al. [20] carried out a complete characterization of corn cobs (\% dry mass): extract total, 19.63 (15.31 water extracts and 4.32 ethanol extracts); cellulose, 22.27 ; hemicelluloses, 28.30 (18.99 xylose, 4.32 galactose, 6.24 arabinose, 2.46 mannose); lignin total, 28.6 (8.65 acid soluble and 19.95 acid non soluble); ash, 6.58 .

\subsection{Bacterial and growth conditions of inocula}

Microorganism used in fermentations was recombinant E. coli cells expressing the PAD gene from $L$. plantarum [21]. Strain was stored in cryovials at $-80^{\circ} \mathrm{C}(20 \%$ glycerol as cryoprotector) to be inoculated into fermentation media. Growth media for inocula were prepared in Erlenmeyer flasks of $250 \mathrm{~mL}$ with $25 \mathrm{~mL}$ of sterile Luria-Bertani (LB) medium containing $10 \mathrm{~g}$ tryptone/L, $10 \mathrm{~g} \mathrm{NaCl} / \mathrm{L}$, $5 \mathrm{~g}$ yeast extract/L and $100 \mathrm{mg}$ ampicillin/L, at $37^{\circ} \mathrm{C}$ and $150 \mathrm{rpm}$ in orbital shakers for growth inocula. $\mathrm{pH}$ was adjusted to 7 and sterilized in autoclave $\left(121^{\circ} \mathrm{C}, 15 \mathrm{~min}\right) .4 \%$ of inocula were added in each experiment [22].

\subsection{Product inhibition assays}

Fermentations to evaluate product inhibition were performed in Erlenmeyer flasks of $250 \mathrm{~mL}$ containing $150 \mathrm{~mL}$ of sterile LB medium (sterilized in autoclave at $121^{\circ} \mathrm{C}$ during $15 \mathrm{~min}$ ) at $37^{\circ} \mathrm{C}$ and $115 \mathrm{rpm}$ in orbital shakers (Optic Ivymen System, Comecta S.A., distributed by Scharlab, Madrid, Spain). Agitation and volume of work for 4VP production were previously optimized by Salgado et al. [22]. The inhibition of 4VP was determined by including $4 \mathrm{VP}$ at various concentrations $(500,1000,1500,2000 \mathrm{mg} 4 \mathrm{VP} / \mathrm{L})$ and $1500 \mathrm{mg} p-\mathrm{CA} / \mathrm{L}$ before inoculation. One additional experiment was performed without 4VP addition as a control. Substrate and 4VP solutions were sterilized by ultrafiltration using $0.22 \mu \mathrm{m}$ membranes (Nalgene). Samples of $1 \mathrm{~mL}$ were recovered along of fermentation in sterile conditions. Samples were centrifuged and analyzed by HPLC. All assays were performed in duplicate.

\subsection{Preparation of media with alkaline hydrolyzates}

Materials were fractionated by two different procedures: alkaline hydrolysis or sequential stages of acid hydrolysis (prehydrolysis) and alkaline hydrolysis.

Pre-hydrolysis of corn cobs was carried out with diluted sulfuric acid (3\%) during $15 \mathrm{~min}$ in ISO glass bottles with caps inside autoclave at $130^{\circ} \mathrm{C}$ with a liquid/solid ratio of $8 \mathrm{~g} / \mathrm{g}$ following the procedure described by Bustos et al. [19].

Raw corncob or solids from the acid treatment were hydrolyzed with solutions of $\mathrm{NaOH}(0.5 \mathrm{~N})$ at room temperature in Erlenmeyer flasks at $150 \mathrm{rpm}$, using a liquid/solid ratio of $0.084 \mathrm{~g}$ solid/g NaOH solution [8]. After $6 \mathrm{~h}$, solids were separated by vacuum filtration, liquors were neutralized with $\mathrm{H}_{2} \mathrm{SO}_{4}(72 \%, \mathrm{w} / \mathrm{v})$ to $\mathrm{pH} 7$, filtrated by vacuum again and stored at $4{ }^{\circ} \mathrm{C}$ for analysis by HPLC.

Detoxification of hydrolyzates media was performed by acidification, reducing the $\mathrm{pH}$ of both alkaline hydrolyzates to $\mathrm{pH} 3$ with $98 \%(\mathrm{w} / \mathrm{w}) \mathrm{H}_{2} \mathrm{SO}_{4}$, followed by centrifugation to remove the precipitate. Finally, supernatants were neutralized to $\mathrm{pH} 7$ with $\mathrm{NaOH}$ $(5 \mathrm{~N})$ and filtered through Whatmann filter paper No. 1.

\subsection{Two-phase biotransformation system}

Fermentations were carried out in Erlenmeyer flasks of $250 \mathrm{~mL}$ with ground glass stoppers with a final volume of $150 \mathrm{~mL}$. Media composition was $75 \mathrm{~mL}$ of aqueous phase (hydrolyzate sterilized by filtration) and $75 \mathrm{~mL}$ of organic phase (hexane). Table 1 shows the hydrolyzates employed in media 1 to 4 . Firstly, aqueous phase was inoculated with $4 \%$ of overnight grown inocula, and then the organic phase was added. A sample of aqueous phase (AP) and organic phase (OP) was taken at each time along the fermentation. Fermentations were carried out in orbital shakers at $110 \mathrm{rpm}$ at $37^{\circ} \mathrm{C}$. Experiments were performed in triplicate.

\subsection{Cell immobilization}

The Ca-alginate method [18] was used to immobilize recombinant $E$. coli cells expressing the $L$. plantarum PAD gene. Microorganism was grown in the same medium that inoculum. After overnight growth, biomass was recovered by centrifugation (Hettich Zentrifugen, Germany) at $2755 \mathrm{~g}$ for $15 \mathrm{~min}$ at $4{ }^{\circ} \mathrm{C}$ and then cells were suspended in $4 \mathrm{~mL}$ of water. A cell suspension containing $1.5 \mathrm{~g} / \mathrm{L}$ was added into $46 \mathrm{~mL}$ of sterilized solution of sodium alginate at $4 \%(\mathrm{w} / \mathrm{v})$. This suspension was pumped with a peristaltic pump (Master flex, Cole Palmer instrument Co.) and dripped into $\mathrm{CaCl}_{2} \cdot 2 \mathrm{H}_{2} \mathrm{O}$-water $2 \%(\mathrm{w} / \mathrm{v})$ to form cell beads with the average diameter of $0.5 \mathrm{~mm}$. After washed with sterilized water, the beads were cultured in fermentation media.

\subsection{Analytical methods}

AP samples, containing the phenolic compounds, were filtered through $0.2 \mu \mathrm{m}$-pore membranes (Sartorius, Goettingen, Germany) in order to analyze the compounds by High Performance Liquid Chromatograph (HPLC), in a chromatograph Agilent model 

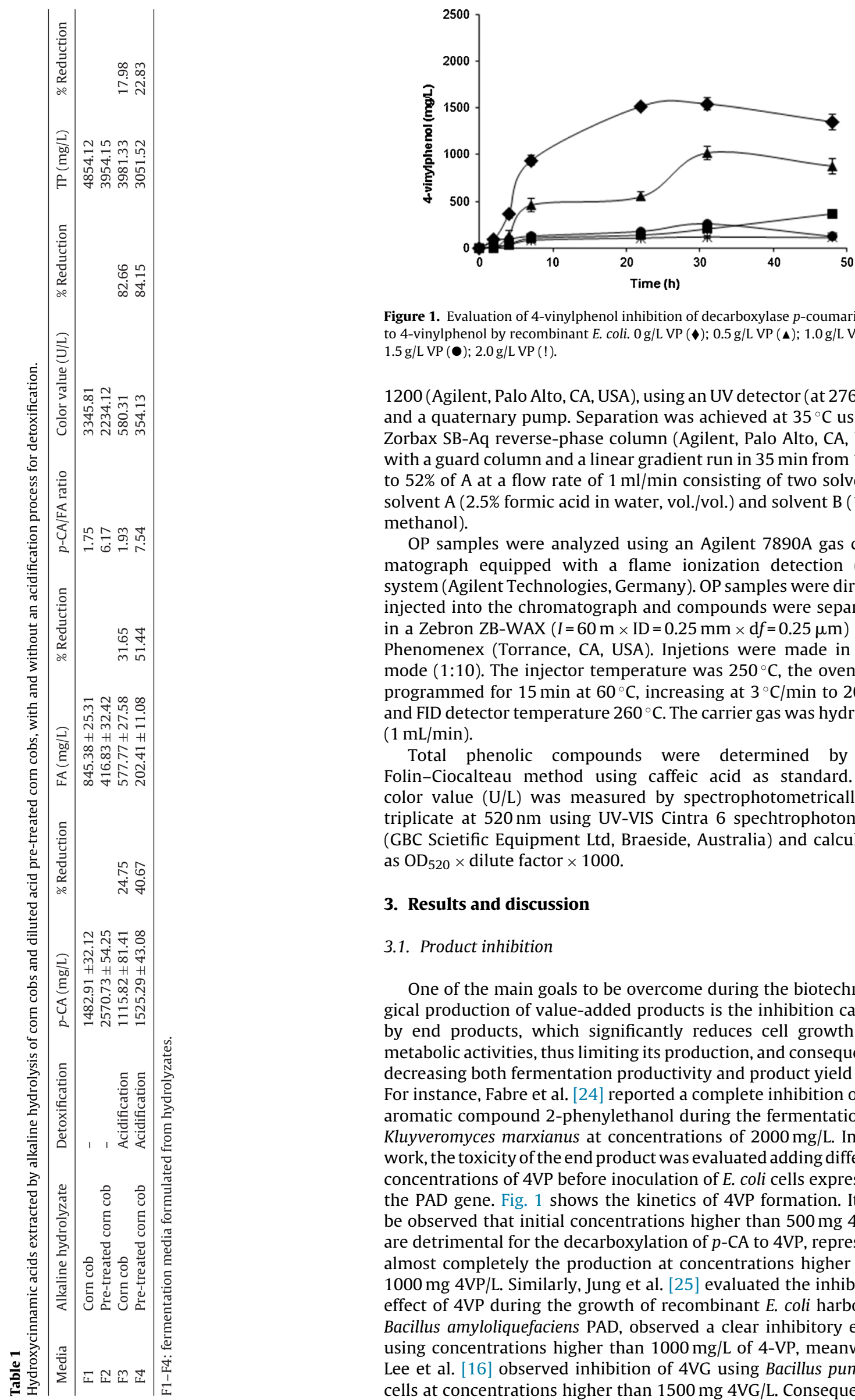

Figure 1. Evaluation of 4-vinylphenol inhibition of decarboxylase $p$-coumaric acid to 4-vinylphenol by recombinant E. coli. $0 \mathrm{~g} / \mathrm{L} \mathrm{VP}(\diamond) ; 0.5 \mathrm{~g} / \mathrm{L} \mathrm{VP}(\boldsymbol{\Delta}) ; 1.0 \mathrm{~g} / \mathrm{L} \mathrm{VP}(\boldsymbol{\square})$; $1.5 \mathrm{~g} / \mathrm{L} \mathrm{VP}(\bullet) ; 2.0 \mathrm{~g} / \mathrm{L} \mathrm{VP}(!)$.

1200 (Agilent, Palo Alto, CA, USA), using an UV detector (at $276 \mathrm{~nm}$ ) and a quaternary pump. Separation was achieved at $35^{\circ} \mathrm{C}$ using a Zorbax SB-Aq reverse-phase column (Agilent, Palo Alto, CA, USA) with a guard column and a linear gradient run in 35 min from $100 \%$ to $52 \%$ of $A$ at a flow rate of $1 \mathrm{ml} / \mathrm{min}$ consisting of two solvents: solvent A (2.5\% formic acid in water, vol./vol.) and solvent B (100\% methanol).

OP samples were analyzed using an Agilent 7890A gas chromatograph equipped with a flame ionization detection (FID) system (Agilent Technologies, Germany). OP samples were directly injected into the chromatograph and compounds were separated in a Zebron ZB-WAX $(I=60 \mathrm{~m} \times \mathrm{ID}=0.25 \mathrm{~mm} \times \mathrm{d} f=0.25 \mu \mathrm{m})$ from Phenomenex (Torrance, CA, USA). Injetions were made in split mode ( $1: 10)$. The injector temperature was $250^{\circ} \mathrm{C}$, the oven was programmed for $15 \mathrm{~min}$ at $60^{\circ} \mathrm{C}$, increasing at $3^{\circ} \mathrm{C} / \mathrm{min}$ to $200^{\circ} \mathrm{C}$ and FID detector temperature $260^{\circ} \mathrm{C}$. The carrier gas was hydrogen ( $1 \mathrm{~mL} / \mathrm{min})$.

Total phenolic compounds were determined by the Folin-Ciocalteau method using caffeic acid as standard. The color value $(\mathrm{U} / \mathrm{L})$ was measured by spectrophotometrically by triplicate at $520 \mathrm{~nm}$ using UV-VIS Cintra 6 spechtrophotometer (GBC Scietific Equipment Ltd, Braeside, Australia) and calculated as $\mathrm{OD}_{520} \times$ dilute factor $\times 1000$.

\section{Results and discussion}

\subsection{Product inhibition}

One of the main goals to be overcome during the biotechnological production of value-added products is the inhibition caused by end products, which significantly reduces cell growth and metabolic activities, thus limiting its production, and consequently decreasing both fermentation productivity and product yield [23]. For instance, Fabre et al. [24] reported a complete inhibition of the aromatic compound 2-phenylethanol during the fermentation by Kluyveromyces marxianus at concentrations of $2000 \mathrm{mg} / \mathrm{L}$. In this work, the toxicity of the end product was evaluated adding different concentrations of $4 \mathrm{VP}$ before inoculation of $E$. coli cells expressing the PAD gene. Fig. 1 shows the kinetics of $4 \mathrm{VP}$ formation. It can be observed that initial concentrations higher than $500 \mathrm{mg} 4 \mathrm{VP} / \mathrm{L}$ are detrimental for the decarboxylation of $p$-CA to 4VP, repressing almost completely the production at concentrations higher than $1000 \mathrm{mg}$ 4VP/L. Similarly, Jung et al. [25] evaluated the inhibitory effect of 4VP during the growth of recombinant $E$. coli harboring Bacillus amyloliquefaciens PAD, observed a clear inhibitory effect using concentrations higher than $1000 \mathrm{mg} / \mathrm{L}$ of $4-\mathrm{VP}$, meanwhile Lee et al. [16] observed inhibition of 4VG using Bacillus pumillus cells at concentrations higher than $1500 \mathrm{mg}$ 4VG/L. Consequently, 
it can be inferred that the accumulation of vinyl derivatives as a product renders a critical constraint in the decarboxylation of hydroxycinnamic acids in aqueous media.

\section{2. $p$-CA extraction from corn cobs}

Corn cobs were assayed as source of $p$-CA to bioproduce 4VP: raw corn cobs and the solid residue obtained after diluted acid hydrolysis pre-treatment, taking into account that $p$-CA can be extracted from corn cobs and pre-treated corn cobs by alkaline hydrolysis using low concentrations of $\mathrm{NaOH}(0.5 \mathrm{~N})$ at room temperature $[8,22]$. Pre-treatmens of lignocellulosic materials is a common step of biorefineries to separate major components cellulose, hemicelluloses and lignin [26]. In this manner, all fractions can be used to obtain different products. In alkaline hydrolysis it is possible solubilize oligosaccharides from the hemicellulosic fraction [8]. The solubilization of hemicelluloses can cause an increase in the viscosity of hydrolyzate [27], thus biotransformation process may be hampered. Torre et al. [8] detected in corn cob alkaline hydrolyzate the solubilization of xylooligosaccharides, arabinooligosaccharides, glucooligosaccharides and acetic acid.

Table 1 shows the concentrations of $p$-CA and FA; the main hydroxycinnamic acids released after alkaline hydrolysis of corn cobs and diluted acid pre-treated corn cobs. Other phenolic compounds are solubilized in alkaline hydrolysis such as syringic acid, p-hydroxybenzoic acid, 3,4-dihydroxybenzaldehyde, gallic acid, vanillic acid [28], but were not released in significant concentrations in this work. Using raw corn cobs directly as substrate, $p$-CA and FA were produced in a ratio of 1.8. Conversely, using the solid residue obtained after pre-hydrolysis, the concentration of $p$-CA increased from $1482.9 \pm 32.1 \mathrm{mg} / \mathrm{L}$ up to $2570.7 \pm 54.2 \mathrm{mg} / \mathrm{L}$, meanwhile the FA decreased from $845.4 \pm 25.3 \mathrm{mg} / \mathrm{L}$ to $416.8 \pm 32.4 \mathrm{mg} / \mathrm{L}$, thus implementing the $p$ $\mathrm{CA} / \mathrm{FA}$ ratio to 6.2 . The concentration of $p$-CA in alkaline hydrolyzate from pre-treated corn cobs was higher than that obtained from non pre-treated corn cob alkaline hydrolyzate. These results suggest that during the acid hydrolysis pre-treatment, $p$-CA was scarcely solubilized, at the time that the physical structure was modified, thus improving the $p$-CA extraction during the alkaline treatment. According to Xu et al. [29] p-CA is presented more extensively esterified to lignin in the cell wall, and hemicelluloses are a physical barrier which could hinder the release of $p$-CA from lignin of cell wall by alkaline hydrolysis. Dilute acid pre-treatment was shown to be able to selectively remove hemicelluloses from different lignocellulosic materials [22,30], and although a small amount of lignin can be solubilized during the dilute acid hydrolysis, the majority is resistant to the attack by dilute acids. [29] However, Salgado et al. [22] observed an important reduction of lignin fraction (approximately $55 \%$ of the initial lignin) during the pre-hydrolysis. This percentage increased up to $86.5 \%$ after both sequential treatments, still remaining a small amount of lignin (4.9\%) in the solid after sequential dilute acid and alkaline hydrolysis. However, the direct alkaline hydrolysis of the raw solid, only allowed releasing $17.6 \%$ of the initial lignin. Despite the lignin reduction observed during the dilute acid hydrolysis, there were no significant losses of $p$-CA $(37.5 \mathrm{mg} / \mathrm{L})$ in this step. Accordingly, $p$-CA was not released from brewer's spent grain during acid pre-treatment [11]. Additionally, a process of detoxification of hydrolyzates, consisting in acidification and further neutralization was assayed to formulate culture media ready to be used during the production of $4 \mathrm{VP}$ by two-phase extractive fermentation. Detoxification treatment removed color substances and reduced total phenolic compounds. Polyphenols responsible of black color can be removed by acid precipitation [31]. Additionally, the acidification reduced $24.8 \%$ and $31.8 \%$ the amount of $p$-CA and FA, respectively, in alkaline hydrolyzates obtained from raw corn cobs. However, these reductions were more drastic in alkaline hydrolyzates from pretreated corn cobs, with percentages of $p$-CA and FA reduction of $40.7 \%$ and $51.4 \%$, respectively.

\subsection{Production of 4VP by two-phase extractive fermentation}

The application of in situ recovery techniques and integrated fermentation-separation processes, often synonymously called extractive fermentation, is a technique to improve some biotechnological processes [23]. Liquid-liquid two-phase systems can be used to overcome microbial limitations in a simple submerged fermentation, such as low substrate solubility, substrate/product inhibition and product further degradation [32]. In this study, fermentation medium (AP) was mixed with an organic solvent (OP), thus recovering $4 \mathrm{VP}$ during fermentation. Consequently, the concentration of toxic compounds in the medium was considerably reduced, avoiding the problems of product inhibition observed, at the same time that product recovery from fermented media was facilitated. In addition, it is avoided the problem derived from a poor solubility of $4 \mathrm{VP}$ in AP which could limit its production.

Hexane has been proposed in 4VP biotransformation in biphasic reactions [1]. However, the use of organic solvents in biocatalytic processes can reduce the enzymatic activity. Thus, in order to evaluate whether a solvent is suitable for bioprocesses, it is taking into consideration the partition coefficient between octanol and water $(\log P)$. It was considered that solvents with a $\log P$ higher than 2 are suitable for biocatalytic systems [17]. The $\log P$ of hexane is 3.29 [1] so that can be used as OP in two-phase extractive fermentations to produce $4 \mathrm{VP}$ by recombinant E. coli. Furthermore, Jung et al. [25] studied remaining PAD activity after incubation with different organic solvents and they observed that the effect of hexane in PAD activity was lower than the other solvents effect. Consequently, in this study, the in situ extractive fermentation was performed to evaluate the continuously recuperation of vinyl derivatives produced in AP by recombinant E. coli using hexane as OP. Fermentations were carried out with crude or detoxified hydrolyzates from direct alkaline hydrolysis of corn cobs ( $p$-CA-AH) or sequential acidic and alkaline hydrolyses ( $p$-CA-AAH). Table 2 shows the results obtained in all fermentations at the maximal concentration of $4 \mathrm{VP}$ (time $24 \mathrm{~h}$ ) as a sum of AP and OP, and at the end of fermentation (time $87 \mathrm{~h}$ ) with both phases separately in order to appreciate the transport from of $4 \mathrm{VP}$ from the AP to the OP.

The production of $4 \mathrm{VP}$ was affected by the process of detoxification. Thereby, fermentations performed using detoxified hydrolyzates achieved higher productions, yields and global volumetric productivity of $4 \mathrm{VP}$. Overliming is a common process employed for detoxification of acid diluted hydrolyzates [33], which allows precipitating toxic compounds at high $\mathrm{pH}$ values [34]. This detoxification process consists in increasing the $\mathrm{pH}$ of the hydrolyzate to extreme values, occurring substance precipitation. The $\mathrm{pH}$ of hydrolyzates after alkaline hydrolysis reached up to 12 , being further reduced to $\mathrm{pH} 3$ by acidification using $\mathrm{H}_{2} \mathrm{SO}_{4}$, and final neutralization to $\mathrm{pH} 7$ with $\mathrm{NaOH}$, producing the precipitation of compounds.

The 4VP concentration was split into two portions, AP and OP. Figure 2a-ddisplay the production of $4 \mathrm{VP}$ and $4 \mathrm{VG}$ during fermentation (bottom of the figure) and the migration of these compounds into the OP (top of the figure). As it was expected, it was observed a higher concentration of $4 \mathrm{VP}$ in AP at the beginning of the fermentation. However, the concentration of 4VP was continuously decreasing in AP, increasing simultaneously in OP, during the course with time of fermentation. Except with detoxified pre-treated corn cob alkaline hydrolyzates (AHH), 4VP was fully recovered at the end of fermentation.

The maximum concentration of 4VP was obtained in fermentation using detoxified $\mathrm{AHH}$, considering the sum of both phases at $24 \mathrm{~h}(1003.5 \mathrm{mg} / \mathrm{L})$ which also represents the highest global 
Table 2

Fermentative parameters of extractive fermentations.

\begin{tabular}{|c|c|c|c|c|c|c|c|c|c|c|c|c|c|c|c|c|c|}
\hline \multicolumn{13}{|c|}{ Sum of product in both phases at $t_{\max }{ }^{*}$} & \multicolumn{3}{|l|}{ Aqueous phase } & \multicolumn{2}{|l|}{ Organic phase } \\
\hline Exp. & Culture & Det. & Imm. & $t_{\max }(\mathrm{h})$ & $\begin{array}{l}{[4 \mathrm{VP}]_{\max }} \\
(\mathrm{mg} / \mathrm{L})\end{array}$ & $\begin{array}{l}{[4 \mathrm{VG}]_{\max }} \\
(\mathrm{mg} / \mathrm{L})\end{array}$ & $\begin{array}{l}Y_{4 \mathrm{VP} / \mathrm{p}-\mathrm{CA}} \\
(\mathrm{mg} / \mathrm{mg})\end{array}$ & $\begin{array}{l}Y_{4 \mathrm{VG} / \mathrm{FA}} \\
(\mathrm{mg} / \mathrm{mg})\end{array}$ & $\begin{array}{l}Q_{4 \mathrm{VP}} \\
(\mathrm{mg} / \mathrm{L} \cdot \mathrm{h})\end{array}$ & $\begin{array}{l}Q_{4 V G} \\
(\mathrm{mg} / \mathrm{L} \cdot \mathrm{h})\end{array}$ & $t_{\mathrm{f}}(\mathrm{h})$ & {$[4 \mathrm{VP}]_{\mathrm{tf}}(\mathrm{mg} / \mathrm{L})$} & {$[4 \mathrm{VG}]_{\mathrm{tf}}(\mathrm{mg} / \mathrm{L})$} & $p$ - $\mathrm{CA}_{\text {cons. }}(\mathrm{mg} / \mathrm{L})$ & $\mathrm{FA}_{\text {cons. }}(\mathrm{mg} / \mathrm{L})$ & {$[4 \mathrm{VP}]_{\mathrm{tf}}(\mathrm{mg} / \mathrm{L})$} & {$[4 \mathrm{VG}]_{\mathrm{tf}}(\mathrm{mg} / \mathrm{L})$} \\
\hline F1 & $\mathrm{AH}$ & - & - & 24 & 685.71 & 87.79 & 0.79 & 1.21 & 28.569 & 1.010 & 87 & 0.0 & $21.73 \pm 3.22$ & $981.83 \pm 8.54$ & $72.61 \pm 38.9$ & $456.59 \pm 13.41$ & $66.2 \pm 3.17$ \\
\hline $\mathrm{F} 2$ & AAH & - & - & 24 & 290.78 & 101.06 & 0.70 & 1.32 & 12.115 & 1.161 & 87 & 0.0 & $44.21 \pm 5.51$ & $724.91 \pm 15.72$ & $76.79 \pm 4.62$ & $159.31 \pm 22.52$ & $56.88 \pm 6.06$ \\
\hline F3 & $\mathrm{AH}$ & + & - & 24 & 641.42 & 89.32 & 0.64 & 0.66 & 26.725 & 1.026 & 87 & 0.0 & $11.58 \pm 0.71$ & $1045.78 \pm 7.29$ & $134.51 \pm 17.89$ & $615.39 \pm 18.48$ & $77.71 \pm 9.43$ \\
\hline F4 & AAH & + & - & 24 & 1003.51 & 76.01 & 0.86 & 1.34 & 41.813 & 0.873 & 87 & $227.81 \pm 8.39$ & $18.79 \pm 0.78$ & $1485.11 \pm 3.22$ & $56.88 \pm 2.49$ & $754.19 \pm 15.22$ & $57.18 \pm 3.63$ \\
\hline F5 & $\mathrm{AH}$ & + & + & 21 & 1013.38 & 74.78 & 1.07 & 0.32 & 48.255 & 1.909 & 38 & $497.29 \pm 11.88$ & $16.11 \pm 0.09$ & $1004.28 \pm 5.29$ & $231.39 \pm 9.11$ & $470.18 \pm 28.41$ & $58.75 \pm 2.22$ \\
\hline F6 & AAH & + & + & 24 & 892.81 & 74.04 & 0.79 & 0.49 & 37.201 & 1.946 & 38 & $437.61 \pm 21.69$ & $15.06 \pm 0.51$ & $1174.11 \pm 4.31$ & $151.52 \pm 10.28$ & $332.11 \pm 10.51$ & $58.81 \pm 1.48$ \\
\hline
\end{tabular}

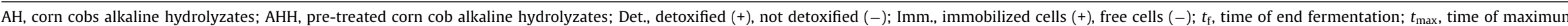

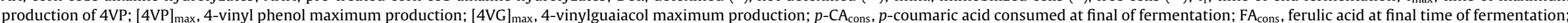
$Y_{4 \mathrm{VP}}$, yield of 4-vinyl phenol at $t_{\max } ; Y_{4 V G}$, yield of 4-vinylguaiacol at $t_{\max } ; Q_{4 \mathrm{VP}}$, volumetric productivity of 4-vinyl phenol at $t_{\max } ; Q_{4 V G}$, volumetric productivity of 4-vinylguaiacol at $t_{\max }$.

"Sum of product in both was expressed in L of aqueous phase.
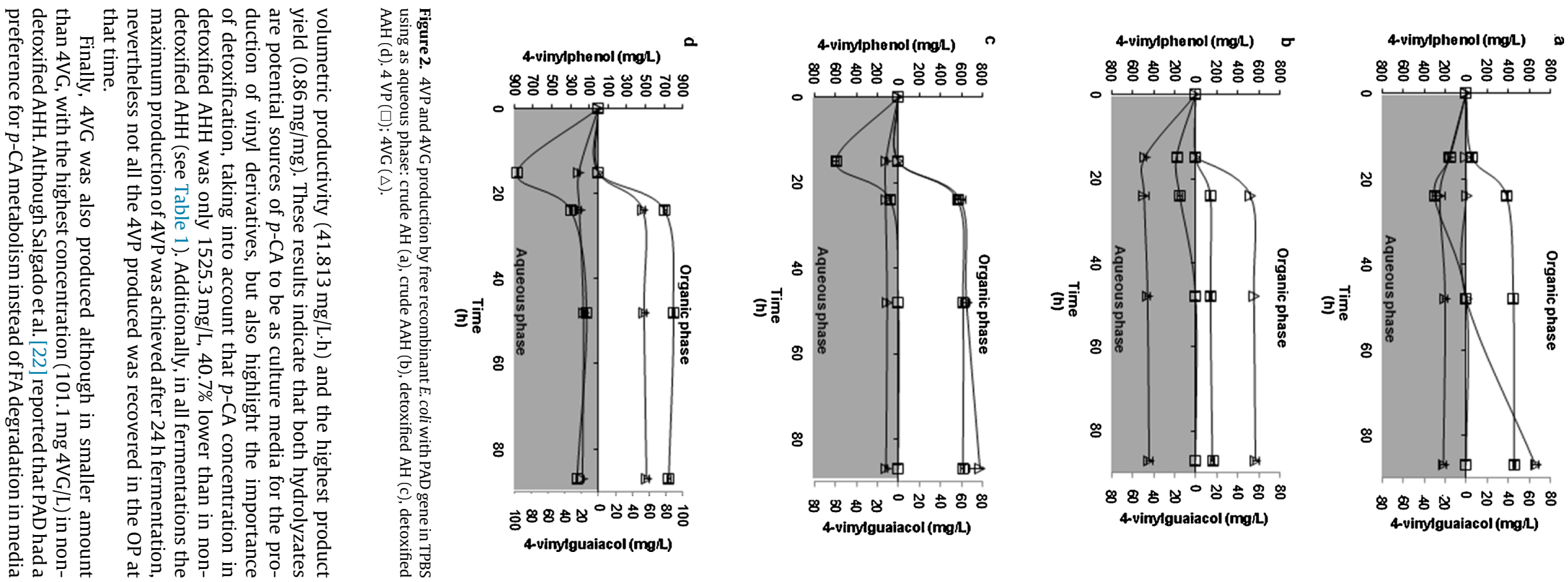


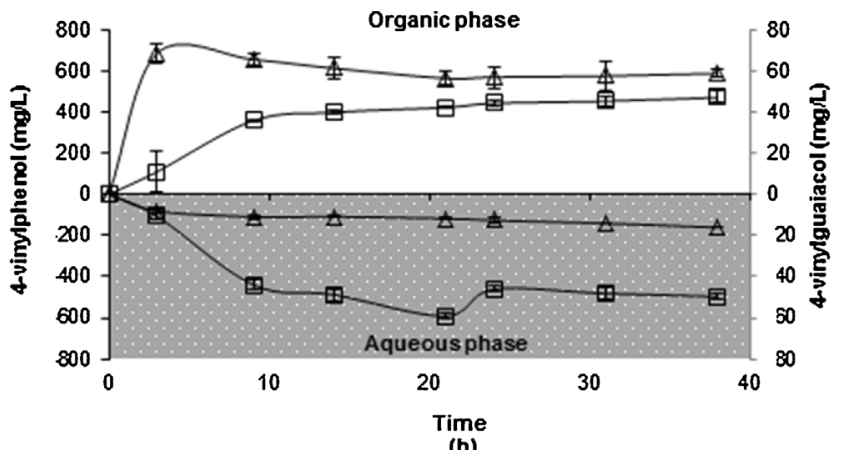

(h)

b

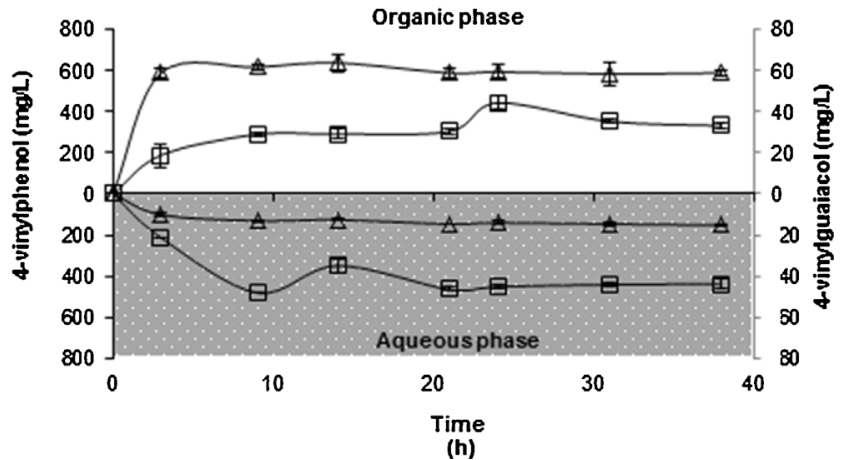

Figure 3. $4 \mathrm{VP}$ and $4 \mathrm{VG}$ production by immobilized recombinant $E$. coli with $\mathrm{PAD}$ gene in TPBS using as aqueous phase: detoxified $\mathrm{AH}$ (a), detoxified $\mathrm{AAH}$ (b). $>4 \mathrm{VP}$ $(\square) ; 4 \mathrm{VG}(\triangle)$.

with both compounds, these low values must be attributed to the lower values of FA present in hydrolyzates (see Table 1 ) rather to the poor conversion, considering the high product yields determined in Table 2. However, conversely to 4VP, 4VG was not efficiently recovered by OP at the end of the fermentation, remaining $44.2 \mathrm{mg} / \mathrm{L}$ in $\mathrm{AP}$ at the end of fermentation $(87 \mathrm{~h})$.

\subsection{Extractive fermentation with immobilized microorganism}

In order to minimize the contact of free cells with OP, preliminary experiments were performed to evaluate the effect of immobilization of cells in alginate beads, therefore avoiding OP toxicity. However, the use of immobilized cells limits mass transfer compared with free cells [17]. In this study, it was observed that recombinant $E$. coli cells expressing the PAD gene immobilized in alginate beads supported 4VP by in situ extractive fermentation using hexane as $\mathrm{OP}$, and $\mathrm{AH}$ and $\mathrm{AHH}$ as AP. Fermentative parameters are shown in Table 2. The production of 4VP in no pre-treated corn cob alkaline hydrolyzates (AH) increased using immobilized cells (up to $1013.4 \mathrm{mg} / \mathrm{g}$ as the sum of two phases after $21 \mathrm{~h}$ fermentation) rather than free cells $(641.4 \mathrm{mg} / \mathrm{g})$; however, using pre-treated corn cob alkaline hydrolyzates $(\mathrm{AHH})$ this concentration decreased slightly, from $1003.5 \mathrm{mg} / \mathrm{L}$ using free cells, to $892.8 \mathrm{mg} / \mathrm{L}$ with immobilized biomass. However, this technology must be optimized, considering that $4 \mathrm{VP}$ was not fully recovered from AP, as it can be seen in Fig. 3a-b in both fermentations, remaining 497.3 and $437.6 \mathrm{mg} / \mathrm{L}$ of $4 \mathrm{VP}$ in $\mathrm{AH}$ and $\mathrm{AHH}$, respectively. Thus, it was observed a negative effect of immobilized cells in the extraction process from AP to OP. In entrapment with calcium alginate some problems such as gel instability in the presence of organic solvents and mass transfer limitations it was observed [17].

\section{Conclusions}

This study has revealed that the biotransformation of $p$-CA to $4 \mathrm{VP}$ by recombinant $E$. coli cells expressing the PAD gene from L. plantarum was affected by the amount of $4 \mathrm{VP}$ in the culture medium. Media with an initial content exceeding $1000 \mathrm{mg} 4 \mathrm{VP} / \mathrm{L}$ had a strong inhibition effect on decarboxylation of $p$-CA to 4VP by PAD. For this reason and to facilitate the product recovery, an in situ extractive fermentation by two phase's system was planned. Alkaline hydrolyzate from no pre-treated corn cobs (AH) and pretreated corn cob alkaline hydrolyzates $(\mathrm{AHH})$ showed to be a good source of $p$-CA. Crude or detoxified hydrolyzates were used as AP in extractive fermentation. Hexane was selected as OP, because it was able to recover effectively the 4VP from AP. The results of this studied demonstrated that detoxified hydrolyzates improved the production of $4 \mathrm{VP}$, especially in $\mathrm{AHH}$. It was also shown that $4 \mathrm{VP}$ could be easily recovered from fermented media. Finally, a preliminary study using cells immobilized in calcium alginate indicated that it was possible the biotransformation of $p$-CA to $4 \mathrm{VP}$, improving the production of 4-vinylphenol using $\mathrm{AH}$, however the recovery of $4 \mathrm{VP}$ from AP was hampered in immobilized cells. Effect of immobilized in recovery of $4 \mathrm{VP}$ is not clear, further detailed studies are required to confirm this assumption. These suggested the need to change OP during fermentation or to use an external solvent column. Further research might investigate this option, as well as the scale-up of the process and the number of cycles.

\section{Acknowledgements}

We are grateful to the Spanish Ministry of Science and Innovation for the financial support of this work (CTQ2011-28967 and AGL2011-22745 projects), which has partial financial support from the FEDER funds of the European Union. J.M.S. is grateful for Postdoctoral fellowship (SFRH / BPD / 84440 / 2012) of Fundação para a Ciência e Tecnologia - FCT.

\section{Appendix A. Supplementary data}

Supplementary data associated with this article can be found, in the online version, at http://dx.doi.org/10.1016/j.enzmictec. 2014.02.005.

\section{References}

[1] Ben-bassat A, Breinig S, Crum GA, Huang L, La A, Altenbaugh B $<$ ET AL $>$. Preparation of 4-vinylphenol using pHCA decarboxylase in a two-solvent medium. Org Process Res Dev 2007;11:145-52.

[2] Bernini R, Mincione E, Barontini M, Provenzano G, Setti L. Obtaining 4 vinylphenols by decarboxylation of natural 4-hydroxycinnamic acids under microwave irradiation. Tetrahedron 2007;63:9663-7

[3] Ayer WA, Muir DJ, Chakravarty P. Phenolic and other metabolites of Phellinus pini, a fungus pathogenic to pine. Phytochemistry 1996;42:1321-4.

[4] Simpson CJ, Fitzhenry MJ, Stamford NPJ. Preparation of vinylphenols from 2hydroxybenzaldehydes. Tetrahedron Lett 2005;46:6893-6.

[5] Torres JL, Rosazza JPN. Microbial Transformations of p-Coumaric Acid by Bacillus megaterium and Curvularia lunata. J Nat Prod 2001;55:1408-14.

[6] Schwarz M, Picazo-bacete JJ, Winterhalter P, Hermosín-gutiérrez I. Effect of copigments and grape cultivar on the color of red wines fermented after the addition of copigments. J Agr Food Chem 2005;53:8372-81.

[7] Yu P, McKinnon JJ, Maenz DD, Racz VJ, Christensen DA. The specificity and the ability of aspergillus feruloyl esterase to release p-coumaric acid from complex cell walls of oat hulls. J Chem Technol Biotechnol 2004;79:729-33.

[8] Torre P, Aliakbarian B, Rivas B, Domínguez JM, Converti A. Release of ferulic acid from corn cobs by alkaline hydrolysis. Biochem Eng J 2008;40:500-6.

[9] Max B, Salgado JM, Cortés S, Domínguez JM. Extraction of phenolic acids by alkaline hydrolysis from the solid residue obtained after prehydrolysis of trimming vine shoots. J Agr Food Chem 2010;58:1909-17.

[10] Gírio FM, Fonseca C, Carvalheiro F, Duarte LC, Marques S, BogelŁukasik R. Hemicelluloses for fuel ethanol: A review. Bioresour Technol 2010;101(13):4775-800.

[11] Mussatto SI, Dragone G, Roberto IC. Ferulic and p-coumaric acids extraction by alkaline hydrolysis of brewer's spent grain. Ind Crops Prod 2007;25:231-7. 
[12] Nakamura Y, Sawada T, Inoue E. Enhanced ethanol production from enzymatically treated steam-exploded rice straw using extractive fermentation. J Chem Technol Biotechnol 2001;76:879-84.

[13] Mihal M, Markoš J, Annus J. Štefuca V. Intensification of 1-phenylethanol production by periodical membrane extraction of the product from fermentation broth. J Chem Technol Biotechnol 2012;87:1017-26.

[14] Yang J, Wang S, Lorrain MJ, Rho D, Abokitse K, Lau PCK. Bioproduction of lauryl lactone and 4-vinyl guaiacol as value-added chemicals in two-phase biotransformation systems. Appl Microbiol Biotech 2009;84:867-76.

[15] Gao F, Daugulis AJ. Bioproduction of the aroma compound 2-phenylethanol in a solid-liquid two-phase partitioning bioreactor system by Kluyveromyces marxianus. Biotechnol Bioeng 2009;104:332-9.

[16] Lee I, Volm TG, Rosazza JPN. Decarboxylation of ferulic acid to 4 vinylguaiacol by Bacillus pumilus in aqueous-organic solvent two-phase systems. Enz Microb Technol 1998;23:261-6.

[17] Leon R, Fernandes P, Pinheiro HM, Cabral JMS. Whole-cell biocatalysis in organic media. Enz Microb Technol 1998;23:483-500.

[18] Pérez-Bibbins B, Salgado JM, Torrado A, Aguilar-Uscanga MG, Domínguez JM. Culture parameters affecting xilitol production by Debaryomyces hansenii immobilized in alginate beads. Process Biochem 2013;48:387-97.

[19] Bustos G, Moldes AB, Cruz JM, Domínguez JM. Production of fermentable media from vine-trimming wastes and bioconversion into lactic acid by Lactobacillus pentosus. J Sci Food Agric 2004;84:2105-12.

[20] Zhang, L., Li, J. -., Li, S. -., \& Liu, Z. L. (2011). Challenges of cellulosic ethanol production from xylose-extracted corncob residues. BioResources, 6(4), 43024316.

[21] Rodríguez H, Landete JM. Curiel JA, de las Rivas B, Mancheño JM, Muñoz R. Characterization of the p-coumaric acid descarboxylase from Lactobacillus plantarum CECT 748 ${ }^{\mathrm{T}}$. J Agric Food Chem 2008;56:3068-72.

[22] Salgado JM, Rodríguez-Solana R. Curiel JA, de las Rivas B, Muñoz R, Domínguez JM. Production of vynil derivatives from alkaline hydrolysates of corn cobs br recombinant Escherichia coli containing the phenolic acid decarboxylase from Lactobacillus plantarum CECT 748. Bioresour Technol 2012;117: 274-85.
[23] Yang ST, Huang H, Tay A, Oin W, De Guzman L, San Nicolas EC. Extractive fermentation for the production of carboxylic acids in Bioprocessing for valuedadded products from renewable resources. Oxford: Elsevier; 2007. p. 421-46.

[24] Fabre CE, Blanc PJ, Goma G. Production of 2-phenylethyl alcohol by Kluyveromyces marxianus. Biotechnol Prog 1998;14:270-4.

[25] Jung DH, Choi W, Choi KY, Jung E, Yun H, Kazlauskas RJ, Kim BG. Bioconversion of p-coumaric acid to p-hydroxystyrene using phenolic acid decarboxylase from B. amyloliquefaciens in biphasic reaction system. Appl Microbiol Biot 2012;97:1501-11.

[26] Romaní A, Garrote G, López F, Parajó JC. Eucalyptus globulus wood fractionation by autohydrolysis and organosolv delignification. Bioresour Technol 2011;102:5896-904

[27] Ou S, Luo Y, Xue F, Huang C, Zhang N, Liu Z. Seperation and purification of ferulic acid in alkaline-hydrolysate from sugarcane bagasse by activated charcoal adsorption/anion macroporous resin exchange chromatography. J Food Eng 2007;78(4):1298-304.

[28] Salgado JM, Max B, Rodríguez-Solana R, Domínguez JM. Purification of ferulic acid solubilized from agroindustrial wastes and further conversion into 4-vinyl guaiacol by streptomyces setonii using solid state fermentation. Indust Crop ProdV 39 2012;(1):52-61.

[29] Xu F, Sun R, Sun J, Liu C, He B, Fan J. Determination of cell wall ferulic and p-coumaric acids in sugarcane bagasse. Anal Chem Acta 2005;552:207-17.

[30] Castro E, Díaz MJ, Cara C, Ruiz E, Romero I, Moya M. Dilute acid pretreatment of rapeseed straw for fermentable sugar generation. Bioresour Technol 2011:102:1270-6.

[31] Hamdi M. Thermoacidic precipitation of darkly coloured polyphenols of olive mill wastewaters. Environ. Technol 1993;14:495-500.

[32] Wang Z, Dai Z. Extractive microbial fermentation in cloud point system. Enz Microb Technol 2010;46:407-18.

[33] Carvalheiro F, Duarte LC, Lopes S, Parajó JC, Pereira H, Gírio FM. Evaluation of the detoxification of brewery's spent grain hydrolysate for xylitol production by Debaryomyces hansenii CCMI 941. Process Biochem 2005;40:1215-23.

[34] Palmqvist E, Hahn-Hägerdal B. Fermentation of lignocellulosic hydrolysates. I: inhibition and detoxification. Bioresour Technol 2000;74:17-24. 